\title{
Profil Kreativitas Siswa dalam Menyelesaikan Soal Segitiga dan Segiempat Ditinjau dari Gender
}

\author{
Devi Febryana \\ Institut Agama Islam Negeri Tulungagung \\ e-mail: devifebryana1@gmail.com
}

\begin{abstract}
This study aims to describe: (1) the level of creative thinking of MTs on a flat wake student gender female, (2) the level of creative thinking of MTs. on a flat wake student gender male. The type of research used in this study is descriptive qualitative research, where the subjects were taken using purposive sampling technique. The subjek of this study were 6 students with details of 3 male students and 3 female students. This study uses data analisys technique triangulation of sources that is by reducing data, presenting data, and draw conclusions. The result of this study are: (1) the level of creative thinking of MTs students on the wake of flat student gender female (creative); and (2) the level of creative thinking of MTs students on the wake of flat student gender male (not creative).
\end{abstract}

Keywords : Level of creative thinking, Gender, Flat Wake

\begin{abstract}
ABSTRAK. Tujuan penelitian ini untuk mendeskripsikan : (1) Tingkat berpikir kreatif siswa MTs. pada konsep bangun datar yang berjenis kelamin laki-laki, (2) Tingkat berpikir kreatif siswa MTs. pada konsep bangun datar yang berjenis kelamin perempuan. Penelitian ini merupakan penelitian kualitatif deskriptif, dimana subjek diambil menggunakan teknik purposif sampling. Subjek penelitian ini berjumlah 6 siswa dengan rincian 3 siswa laki-laki dan 3 siswa perempuan. Pada penelitian ini menggunakan teknik analisis data trianggulasi sumber yaitu reduksi data, menyajikan data dan menarik kesimpulan. Hasil dari penelitian ini adalah : (1) Tingkat berpikir kreatif siswa MTs pada konsep bangun datar yang berjenis kelamin perempuan (kreatif) (2) Tingkat berpikir kreatif siswa MTs pada konsep bangun datar yang berjenis kelamin laki-laki (tidak kreatif)
\end{abstract}

Kata kunci: Tingkat berpikir kreatif, jenis kelamin, bangun datar

\section{PENDAHULUAN}

Matematika berperan sebagai sarana mengembangkan daya nalar, karena belajar matematika berarti belajar cara mengembangkan kemampuan berpikir. Oleh sebab itu, matematika dapat dipandang sebagai cara berpikir, sebagaimana dikemukakan Jacob \& Sam (2008) bahwa, matematika tidak hanya dipandang sebagai cabang ilmu pengetahuan dan mata pelajaran, tetapi juga dipandang sebagai cara siswa berpikir. Berpikir merupakan suatu kegiatan mental yang melibatkan kerja otak, dan seseorang dikatakan berpikir bila orang itu melakukan kegiatan mental (Hudojo, 2003). Jadi, berpikir merupakan satu kegiatan mental pribadi manusia yang mengakibatkan penemuan yang terarah kepada suatu tujuan. Pada aspek yang lain, berpikir merupakan kemampuan untuk menyelesaikan masalah atau tugas dan menyelesaikannya dengan cara cerdas dan rasional sehingga dapat memberikan penjelasan yang masuk akal atau logis (Tomasello, 2014; Ngang, Nair, \& Pracak, 2013). Salah satu harapan dan tujuan penting yang harus dicapai oleh siswa dalam belajar matematika, yakni memiliki kemampuan berpikir, sebagaimana yang tercantum dalam Peraturan Menteri Pendidikan Nasional Republik Indonesia nomor 23 tahun 2006 tentang Standar Kompetensi Lulusan (SKL) untuk Satuan Pendidikan Dasar dan Menengah. 
Pendidikan mempengaruhi pola berpikir serta cara pandang seseorang terhadap suatu masalah. Cara pandang tersebut dipengaruhi oleh kreativitas. Semakin kreatif maka akan semakin besar peluang untuk berhasil. Bagian dari pendidikan yang membekali siswa untuk berpikir kreatif adalah matematika. Hal ini sejalan dengan Dreyfus, Eisenberg dan Ginsburg dalam Mann (2006) yang menyatakan bahwa inti dari matematika adalah berpikir kreatif, bukan sekedar menghasilkan jawaban yang benar. Berpikir kreatif adalah kemampuan menemukan banyak kemungkinan jawaban terhadap suatu masalah, dimana penekanannya pada kuantitas, ketepatgunaan, dan keberagaman jawaban berdasarkan data atau informasi yang tersedia. (Utami Munandar, 2009:48) Berpikir kreatif siswa sangat mempengaruhi keberhasilan belajar matematika. Keberhasilan pembelajaran matematika dapat dilihat dari hasil belajarnya. Hasil belajar matematika siswa SMP Negeri 2 Kalidawir menunjukkan bahwa 93\% dari 32 siswa tidak mencapai KKM. Hal ini menunjukan bahwa tujuan pembelajaran matematika tidak berhasil dicapai. Ketidakberhasilan ini dipengaruhi oleh beberapa faktor diantaranya kurangnya motivasi, kurangnya pemahaman konsep, kurang menariknya proses pembelajaran, dan ketidakkreatif siswa dalam menyelesaikan permasalahan. Ketidak kreatif siswa dalam menyelesaikan masalah terlihat dari hasil pekerjaan siswa yang hanya menjawab sesuai dengan yang diajarkan gurunya, siswa tidak mencari alternatif lain setiap menyelesaikan permasalahan dan siswa mengalami kesulitan dalam menyelesaikan soal yang dikembangkan oleh gurunya. Hasil dari berpikir kreatif disebut kreativitas. Pada dasarnya kreativitas merupakan prestasi yang istimewa dalam menciptakan sesuatu yang baru berdasarkan bahan, informasi, data atau elemen yang sudah ada sebelumnya menjadi hal-hal yang berbeda dan bermanfaat. Sependapat dengan Karkockiene (2005) bahwa kreativitas melibatkan karakteristik yang berhubungan dengan kemampuan seseorang untuk menemukan atau melakukan sesuatu yang baru. Sesuatu yang baru ini bukan hal yang mutlak baru, tetapi dapat juga merupakan suatu kombinasi dengan cara-cara yang sudah ada. Sejalan dengan Muhammad Ali dan Muhammad Asrori (2011) yang menyatakan bahwa kreativitas adalah kemampuan seseorang untuk menciptakan sesuatu yang sama sekali baru atau kombinasi dari karya-karya yang telah ada sebelumnya menjadi sesuatu karya baru yang dilakukan melalui interaksi dengan lingkungannya untuk menghadapi permasalahan dan mencari alternatif pemecahannya melalui cara-cara berpikir divergen. Indikator kemapuan berpikir kreatif adalah kefasihan, flesibilitas, dan kebaruan. Hal ini sejalan dengan Silver (1997) menyatakan bahwa kreativitas pemecahan masalah diindikasi dengan kefasihan (fluency), fleksibilitas (flexibility), kebaruan (novelty). Penjelasan dari masing-masing indikator dijelaskan oleh Endang Krinawati (2012) aspek kefasihan mengacu pada kebenaran dan keberagaman jawaban yang diberikan siswa, aspek fleksibilitas mengacu pada cara-cara yang berbeda yang diberikan oleh siswa dalam menyelesaikan masalah, sedangkan aspek kebaruan mengacu kepada jawaban yang diberikan tidak biasa untuk tingkat pengetahuan siswa pada umumnya dan juga bisa mengacu kepada cara baru yang ditampilkan siswa, cara baru ini bisa saja merupakan cara kombinasi dari pengetahuan yang didapat siswa sebelumnya. Salah satu faktor yang mempengaruhi pola berpikir kreatif siswa adalah jenis kelamin (gender). Zubaidah Amir MZ (2013) mengemukakan bahwa gender berasal dari bahasa latin, yaitu genur yang berarti tipe atau jenis. Sri Subarinah (2013) Gender merupakan karakteritik yang membedakan antar individu-individu. Gender merupakan jenis kelamin bawaan lahir yang dipengaruhi oleh faktor sosial dan budaya. Beberapa penelitian menunjukan bahwa hasil belajar siswa laki-laki lebih baik dibandingkan siswa perempuan. Hal ini sejalan dengan Aminah Ekawati dan Shinta Wulandari (2011) mengatakan bahwa perempuan lemah dalam persoalan yang berkaitan dengan abstrak, yang berakibat bahwa perempuan dianggap lemah dan kurang mampu dalam mempelajari matematika. Namun penelitian Nurmitasari (2016) memberikan hasil bahwa siswa laki- laki dan siswa perempuan memiliki prestasi belajar yang sama baiknya. Sedangkan Krutetzky dalam Ahmad Hatip (2008) menyatakan bahwa dalam berpikir siswa perempuan lebih unggul dalam ketepatan, kecermatan, ketelitian dan keseksamaan. Berbeda dengan siswa laki-laki yang cenderung kurang teliti dan cenderung menyelesaikan sesuatu secara cepat. Hal ini menunjukan bahwa berpikir kreatif siswa laki-laki dan perempuan berbeda, begitu pula tingkat berpikir kreatifnya. Sependapat dengan Muhammad Ilham 
Nafi'an (2011) bahwa perbedaan jenis kelamin tidak lagi hanya berkaitan dengan masalah biologis saja tetapi kemudian berkembang menjadi perbedaan kemampuan antara laki-laki dan perempuan. Tingkat berpikir kreatif siswa didasarkan pada tiga komponen yaitu kefasihan, fleksibelitias, serta originalitas. Teori hipotetik tingkat berpikir kreatif ini dinamakan dengan draf tingkat berpikir kreatif. Tingkat berpikir kreatif ini menekankan pada pemikiran divergen dengan aspek yang paling penting adalah kebaruan, kemudian fleksibelitas serta yang peling rendah adalah fasih. Kebaruan ditempatkan pada posisi yang paling tinggi karena merupakan ciri utama dari menilai suatu produk kreatif, yaitu harus berbeda dari sebelumnya. Fleksibelitas ditempatkan dalam posisi yang kedua karena menunjukan adanya produktivitas ide yang digunakan untuk menyelesaikan sesuatu masalah. Kefasihan menunjukan pada kelancaran siswa memproduksi ide yang berbeda sesuai dengan permintaan.

Dalam proses pembelajaran matematika di kelas, salah satu konsep yang diberikan adalah bangun datar khususnya segitiga dan segiempat. Dalam materi ini siswa dikenalkan bentuk-bentuk bangun datar, sifat-sifat yang dimiliki bangun datar, menghitung keliling dan luas bangun datar, serta aplikasinya dalam kehidupan sehari-hari. Kesemuanya itu membutuhkan imajinasi serta proses berpikir kreatif dalam setiap penyelesaian masalahnya. Siswa tidak hanya dituntut untuk dapat menyelesaikan rumus sesuai dengan apa yang diberikan gurunya, tetapi yang lebih penting adalah siswa dapat menemukan rumus sendiri serta mengaplikasikannya dalam setiap menyelesaikan permasalahan. Dari uraian-uraian tersebut terlihat bahwa terdapat perbedaanperbedaan mendasar pada siswa dalam penggunaan fungsi kognitifnya, yang selanjutnya akan berpengaruh terhadap berpikir kreatif dan hasil belajar siswa.

\section{METODE PENELITIAN}

Jenis penelitian ini merupakan penelitian deskriptif, dengan pendekatan kualitatif, yaitu penelitian menggunakan data kualitatif dan dideskripsikan untuk menghasilkan gambaran yang jelas dan terperinci mengenai kemampuan berpikir peserta didik dalam memecahkan soal bangun datar.

Penelitian ini dilakukan di kelas VIIB MTs Sunan Kalijaga Kalibatur pada semester genap, tahun ajaran 2017-2018. Penelitian ini dilaksanakan sesuai jadwal pelajaran matematika di sekolah tersebut. Subyek penelitian ini adalah peserta didik kelas VIIB MTs Sunan Kalijaga Kalibatur, dengan pertimbangan bahwa peserta didik pada sekolah ini memiliki kemampuan yang heterogen.

Metode pengumpulan data metode yang digunakan adalah:

1. Tes

Tes ini dilakukan untuk

a. Mengetahui kemampuan peserta didik dalam memecahkan masalah matematika.

b. Untuk mengkroscek antara tes dengan wawancara

2. Wawancara

Metode wawancara ini dilakukan untuk memperoleh data proses berpikir kreatif peserta didik dalam memecahkan masalah matematika bangun datar. Wawancara dilakukan sesuai dengan kemampuan peserta didik dalam mengerjakan soal (tes). Pada saat wawancara dilakukan, pewawancara mengambil data dibantu dengan menggunakan alat yaitu:

a. Pedoman Wawancara

Sebelum wawancara dilaksanakan peneliti menyiapkan pedoman wawancara berpikir kreatif dahulu.

b. Kaset Audio (Perekam)

Pada saat wawancara dilakukan, pewawancara menyiapkan kaset audio agar mempermudah dan memperjelas dalam pencatatan wawancara. 
Adapun instrumen penelitian yang akan digunakan dalam penelitian ini sebagai berikut: a. Soal Tes

Untuk mengetahui kemampuan pemecahan masalah matematika dilakukan dengan memberikan soal tes. Soal tes yang diberikan adalah soal tes yang berupa soal bangun datar. Soal bangun datar yang digunakan adalah materi yang telah diajarkan oleh peneliti. Soal tes ini dibuat oleh peneliti maupun diadaptasi dari kitab pelajaran yang sudah ada, kemudian dikonsultasikan dengan dosen pembimbing. Peserta didik diminta untuk memberikan jawaban dari masing-masing soal yang diberikan dengan menggunakan langkah-langkah dalam mengerjakan soal matematika..

b. Pedoman wawancara

Wawancara dilakukan untuk memperoleh data kualitatif tentang kemampuan berpikir kreatif peserta didik dalam pemecahan masalah matematika dengan menggunakan metode wawancara terbuka (Moleong 2007: 188). Pengertian baku menunjukkan bahwa materi yang ditanyakan dan cara penyajian sama untuk setiap responden, sedangkan pengertian terbuka adalah adanya keluwesan pertanyaan.

Analisis penelitian yang diperoleh dalam penelitian ini dimaksudkan untuk menjawab pertanyaan penelitian dalam rangka merumuskan kesimpulan. Data yang diperoleh adalah data soal tes dan wawancara. Selanjutnya seluruh data tersebut dianalisis dengan analisis sebagai berikut:

1. Tes

Analisis data dari hasil tes pemecahan masalah matematika dalam bentuk soal bangun datar dilakukan dengan dengan tujuan :

a. Untuk mengukur kemampuan peserta didik dalam mengerjakan soal dengan cara menyekor hasil tes pemecahan masalah matematika bentuk soal cerita peserta didik berpandu pada alternatife jawaban dan pedoman penyekoran yang telah dibuat. Peserta didik diminta untuk memberikan jawaban dari masing-masing soal yang diberikan dengan menggunakan langkah-langkah dalam mengerjakan soal matematika bentuk bangun datar.

b. Untuk pemilihan subyek wawancara dilakukan dengan cara mengelompokkan peserta didik.

2. Wawancara

Analisis terhadap wawancara ini untuk mengetahui proses berpikir kreatif peserta didik dilakukan dengan menggunakan analisis non statistik yaitu. Setelah mendapatkan hasil wawancara kemudian dianalisis dengan langkah-langkah berikut (Moleong : 2007):

a. Reduksi data

Reduksi data adalah kegiatan menyeleksi, memfokuskan data yang diperoleh dari wawancara. Data wawancara yang terkumpul kemudian dianalisis guna merumuskan tujuan peneliti.

b. Penyajian data

Setelah reduksi data, data dari hasil wawancara berpikir kreatif peserta didik maka hasil tersebut dideskripsikan dengan cara kualitatif.

c. Penarikan kesimpulan

Penarikan kesimpulan dilakukan berdasarkan analisis data yang dikumpulkan. Berdasarkan analisis data tersebut diadakan penafsiran untuk mendapatkan kesimpulan.

\section{HASIL DAN PEMBAHASAN}

Berdasarkan hasil tes berpikir kreatif pada bangun datar dan wawancara yang telah dilakukan peneliti kepada subjek penelitian diperoleh data sebagai berikut:

1. Tingkat berpikir kreatif siswa yang berjenis kelamin perempuan 
Hasil analisis tes tertulis dan wawancara kepada 3 subjek yang berjenis kelamin perempuan sebagai berikut.

a. Subjek $A B$ Untuk soal nomor 1, $A B$ dapat mengerjakan soal dengan lancar secara tertulis. $\mathrm{AB}$ dapat membuat bangun datar yang berbeda tetapi memiliki luas yang sama dengan bangun datar yang diketahui. Namun setelah diklarifikasi degan menggunakan wawancara, subjek tidak dapat menjelaskan dengan benar berdasarkan hasil tes tertulis yang sudah ia kerjakan. Hal ini memberikan kesimpulan bahwa subjek belum memenuhi indikator kefasihan. Dalam mengerjakan soal nomor 2, jawaban pada tes tertulis $\mathrm{AB}$ sudah menunjukan kebaruan. Jawaban $\mathrm{AB}$ berbeda dengan jawaban siswa pada umumnya. Dari wawancara diperoleh bahwa AB menguasai konsep dasar tentang bangun datar sehingga pertanyaan peneliti dijawab dengan benar oleh AB. Oleh karenanya $\mathrm{AB}$ sudah memenuhi indikator kebaruan. Soal nomor 3, pada tes tertulis $A R$ tidak menjelaskan secara rinci cara untuk menemukan bangun datar lain yang luasnya sama dengan bangun datar yang diketahui (persegi panjang). AB hanya mampu membuat sketsa sederhana dari sebuah persegi panjang menjadi trapesium. Berdasarkan wawancara diperoleh bahwa AB dengan tegas mengatakan tidak bisa menyelesaikan soal. Hal ini memberikan kesimpulan bahwa AB tidak bisa menemukan cara yang berbeda-beda untuk menemukan luas yang sama. Oleh karenanya AB belum mampu memenuhi indikator fleksibilitas.

b. Subjek CA Pada soal nomor 1, AC dapat membuat bangun datar yang berbeda tetapi memiliki luas yang sama dengan bangun datar yang diketahui. AC juga mampu menjelaskan dengan lancar kepada peneliti saat diwawancarai bagaimana cara mendapatkan bangun datar yang berbeda tetapi memiliki luas yang sama dengan bangun datar yang diketahui. Hal ini menunjukan bahwa AC memenuhi indikator kefasihan. Untuk soal nomor 2, AC dapat membuat gabungan dua buah bangun datar yang memiliki luas sama dengan bangun datar yang telah diketahui secara tertulis. Bangun datar yang dibuat oleh AC ialah bangun datar yang baru. Secara wawancara pun AC dapat menyebutkan dua bangun datar yang masing- masing luasnya jika digabungnya sama dengan luas bangun datar yang diketahui. Namun sama dengan tes tertulis bangun datar yang disebut bangun datar yang baru. Hal ini menunjukakan bahwa AC sudah memenuhi indikator kebaruan. Soal nomor 3, AC mengerjakan soal tidak sesuai dengan pertanyaan secara tertulis. Kemudian saat wawancara AC tidak dapat memberikan penjelasan bagaimana cara lain untuk mendapatkan bangun datar yang baru. Hal ini menunjukan bahwa AC belum memenuhi indikator fleksibilitas.

c. Subjek DU Untuk soal nomor 1, DU dapat membuat bangun datar lain yang memiliki luas sama dengan bangun datar yang diketahui secara tertulis. Dan dapat menyebutkan secara wawancara. Ini menunjukan bahwa DU memenuhi indikator kefasihan. Soal nomor 2, DU tidak mampu membuat gabungan dua bangun datar yang baru yang memiliki luas sama dengan yang dketahui. DU membuat bangun datar yang sama dengan yang dibuat oleh siswa lainnya pada tes tertulis. Begitu pula pada wawancara penjelasan DU belum menunjukan keterbaruan, karena DU tidak dapat menyebutkan dua bangun datar lain yang sifatnya baru. Ini menunjukan bahwa DU belum memenuhi indikator kebaruan. Pada soal nomor 3, baik secara tertulis maupun secara wawancara DU dapat menemukan cara yang baru untuk menemukan atau membuat bangun datar lain yang memiliki luas yang sama dengan salah satu bangun datar pada soal nomor 2 . Ini menunjukan bahwa DU bisa memenuhi indikator fleksibilitas.

Berdasarkan uraian pada masing- masing subjek, selanjutnya dilakukan triangulasi sumber. Data yang berbeda akan direduksi atau dijadikan temuan lain. Adapun rangkuman hasil analisis data dari masing-masing subjek terlihat pada Tabel 1. 
Tabel 1. Rangkuman hasil analisis data subjek berjenis kelamin perempuan

\begin{tabular}{clcccc}
\hline No & Subjek & Kefasihan & Kebaruan & Fleksibilitas & Jumlah \\
\hline 1 & Anisa Bilqis & - & $\sqrt{ }$ & - & 1 \\
\hline 2 & Cantika Anandi & $\sqrt{ }$ & $\sqrt{ }$ & $\sqrt{ }$ & 3 \\
\hline 3 & Delisa U. & $\sqrt{ }$ & - & - & 1 \\
\hline
\end{tabular}

Berdasarkan Tabel 1. tersebut dapat disimpulkan bahwa subjek dengan jenis kelamin perempuan ada yang memenuhi tiga indikator berpikir kreatif yaitu kefasihan, kebaruan dan fleksibilitas. Hal ini berarti siswa perempuan kreatif dalam menyelesaikan soal matematika.

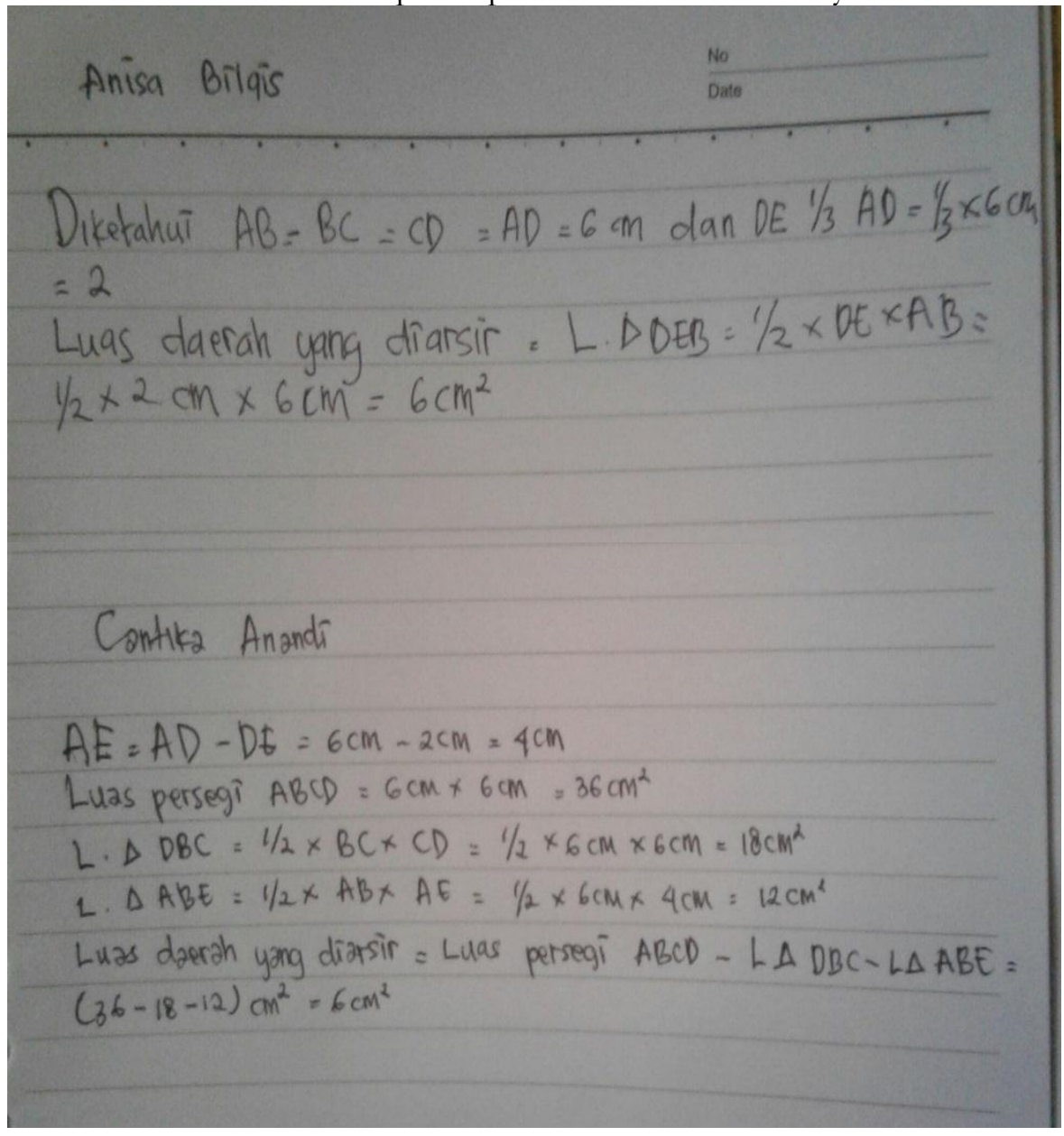

2. Tingkat berpikir kreatif siswa yang berjenis kelamin laki-laki

Hasil analisis tes tertulis dan wawancara kepada 3 subjek yang berjenis kelamin lakilaki sebagai berikut.

a. Subjek AH Dari hasil tes tertulis dan wawancara diperoleh bahwa pada soal nomor 1, AH belum bisa membuat dan menjelaskan bangun datar lain yang memiliki luas yang sama dengan bangun datar yang diketahui. Hal ini menunjukan bahwa AH belum mampu memenuhi indikator kefasihan. Pada soal nomor 2, subjek AH dapat menjawab dengan benar baik dari segi prosedur maupun dari segi hasil. Akan tetapi bangun yang dibuat belum bersifat baru. Ini mengindikasi bahwa $\mathrm{AH}$ belum memenuhi indikator kebaruan. Untuk soal nomor 3, subjek AH tidak menunjukan cara yang berbeda dalam menemukan dan membuat bangun datar pada soal nomor 2. AH juga tidak tahu nama bangun datar yang ia buat. Ini menunjukan bahwa $\mathrm{AH}$ tidak memenuhi indikator fleksibilitas. 
b. Subjek DA Pada soal nomor 1, hasil tes yang dikerjakan secara tertulis subjek dapat menggambarkan bangun datar lain yang memiliki luas sama dengan bangun datar yang diketahui. Namun subjek masih salah didalam prosedur penyelesaiannya. Subjek salah dalam memberikan ukuran pada bangun datar yang ia buat. Kemudian subjek diklarifikasi dengan wawancara, subjek menjelaskan hasil pekerjaanya dengan raguragu dan menyebutkan ukuran bangun datar ia buat secara benar. Ini menunjukan bahwa subjek DA belum mampu memenuhi indikator kefasihan. Dari hasil tes yang dikejakan pada nomor 2, subjek hanya dapat menggambarkan serta menuliskan ukurannya, namun prosedur yang dikerjakan masih salah. Selain itu jawaban yang dihasilkan juga tidak baru, masih bersifat sama dengan yang siswa lain pada umumnya. Kemudian diklarifikasi dengan wawancara subjek tidak mengetahui ukuran bangun yang ia buat. Subjek juga tidak dapat menggambar bangun datar lain yang sifatnya baru yang memiliki luas yang sama dengan bangun datar yang diketahui. Hal ini menunjukan bahwa subjek DA belum memenuhi indikator kebaruan. Subjek tidak menuliskan jawaban pada soal nomor 3. Setelah melakukan wawancara, subjek dapat menjelaskan dengan baik bagaimana cara membuat bangun datar lain yang luasnya sama dengan bangun datar pada nomor 2 yaitu dengan cara dipotong. Subjek mampu menjelaskan bangaimana membuat bangun datar yang diketahui menjadi dua bangun datar yang lainnya. Hal ini menunjukan bahwa DA telah memenuhi indikator fleksibilitas.

c. Subjek CM Dari hasil tes yang dikerjakn pada nomor 1 secara tertulis, subjek CM masih salah dalam prosedur penyelesaiannya. Hal ini ditunjukan dengan subjek yang masih salah dalam memasukkan ukuran bangundatar yang ia buat kedalam rumus dan akhirnya mmberikan hasil yang salah. Setelah diklarifikasi dengan menggunkan wawancara subjek juga tidak dapat menjelaskan dengan lancar, terlihat subjek tidak dapat menyebutkan ukuran bangun datar yang dibuatnya. Ini menunjukan bahwa subjek CM belum memenuhi indikator kefasihan. Untuk soal nomor 2, hasil tes tertulis yang dikerjakn subjek menunjukan bahwa subjek masih salah dalam memasukan ukuran bangun datar yang ia buat kedalam rumus. Karena prosedur yang dilakukan salah maka di peroleh hasil yang salah pula. Jawaban yang diberikan subjek juga merupakan jawaban yang biasa dibuat oleh siswa lain pada umumnya. Kemudian subjek diklarifkasi menggunakan wawancara. Subjek pun menjawaban ukuran bangun datar yang disebutkan salah. Kemudian subjek juga tidak dapat mencari bangun datar lain yang memiliki sifat baru. Hal ini menunjukan bahwa subjek CM belum memenuhi indikator kebaruan. Hasil pekerjaan subjek soal nomor 3 secara tertulis, subjek belum dapat menerapkan cara brbeda untuk menemukan atau membuat bangun datar pada soal nomor 2. Ketika ditanya mengenai cara berbeda untuk menemukan luas yang sama subjek terlihat kesulitab dalam menjawab, dan hanya menjawab dipotong tanpa menjelaskan bagaimana memotongnya. Ini memberikan indikasi bahwa subjek CM belum memenuhi indikator fleksibilitas.

Berdasarkan uraian pada masing- masing subjek tingkat berpikir kreatif yang berjenis kelamin laki-laki, selanjutnya dilakukan triangulasi sumber. Data yang berbeda akan direduksi atau dijadikan temuan lain. Adapun rangkuman hasil analisis data dari masing-masing subjek terlihat pada Tabel 2 .

Tabel 2. Rangkuman hasil analisis data subjek berjenis kelamin laki-laki

\begin{tabular}{clcccc}
\hline No & Subjek & Kefasihan & Kebaruan & Fleksibilitas & Jumlah \\
\hline 1 & Ahmad Hasan & - & - & - & 0 \\
\hline 2 & Doni Ali & - & - & $\sqrt{ }$ & 1 \\
\hline 3 & Candra Mahmud & - & - & - & 0 \\
\hline
\end{tabular}


Berdasarkan Tabel 2. tersebut dapat disimpulkan bahwa subjek dengan jenis kelamin laki-laki hanya memenuhi satu indikator berpikir kreatif yaitu fleksibilitas.

Dari analisis data yang telah teruraikan maka diperoleh bahwa siswa perempuan bisa di katakan lebih kreatif dari siswa laki-laki. Soal untuk mendapatkan data berpikir kreatif merupakan soal yang divergen yang membutuhkan pemahaman dalam menyelesaikannya. Sehingga jika dilakukan perbandingan siswa perempuan memiliki tingkat berpikir kreatif yang lebih baik dari siswa laki-laki.

\section{KESIMPULAN}

Berdasarkan analisis data dan pembahasan maka diperoleh simpulan sebagai berikut.

a. Tingkat berpikir kreatif siswa MTs Sunan Kalijaga Kalibatur kelas VII.B pada semester genap tahun ajaran 2017/2018 yang berjenis kelamin perempuan ( kreatif). Hal ini ditunjukkan dengan siswa mampu menunjukan kefasihan, fleksibilitas dan kebaruan.

b. Tingkat berpikir kreatif siswa MTs Sunan Kalijaga Kalibatur kelas VII.B pada semester genap tahun ajaran 2017/2018 yang berjenis kelamin laki-laki (tidak kreatif). Hal ini ditunjukan dengan siswa yang hanya mampu menunjukan fleksibilitas saja.

\section{DAFTAR PUSTAKA}

Abdul Karim. 2014. Mengembangkan Berfikir Kreatif Melalui Membaca dengan Model Mind Map. Volume 2 No. 1.

Ardianto Pandapotan Siregar, Dwi juniati, Raden Sulaiman. 2017. Profil Berfikir Fungsional Siswa SMP dalam Menyelesaikan Masalah Matematika Ditinjau dari Perberdaan Jenis Kelamin. Jurnal Riview Pembelajaran Matematika. http://jrpm.uinsby.ac.id

Erlan Siswandi, Imam Sujadi, Riyadi. 2016. Analisis Kesalahan Siswa dalam Menyelesaikan Masalah Matematika Kontekstual pada Materi Segiempat Berdasarkan Analisis Newman Ditinjau dari Perbedaan Gender.Jurnal Elektronik Pembelajaran Matematika. Vol.4 No.7 ISSN: 2339- 1685.

Isnaeni Umi Machromah, Riyadi, Budi Usodo. 2015. Analisis Proses dan Tingkat Berfikir Kreatif Siswa SMP dalam Pemecahan Masalah Bentuk Soal Cerita Materi Lingkaran Ditinjau dari Kecemasan Matematika. Jurnal Elektronik Pembealajaran Matematika. Vol.3 No.6, hal 613624 ISSN 2339-1685.

Muhammad Bakhril Ilmi dan Abdul Haris Rosyidi. 2017. Penalaran Siswa SMA dalam Pembuktian Matematika pada Materi Trigonometri Ditinjau dari Perbedaan Jenis Kelamin. Jurnal Ilmiah Pendidikan Matematika. Volume 3 No.6.

Musdalifah Asis, Nurdin Arsyad, Alimuddin. 2015. Profil Kemampuan Spasial dalam Menyelesaikan Masalah Geometri Siswa yang Memiliki Kecerdasan Logis Matematis Tinggi Ditinjau dari Perbedaan Gender. Jurnal Daya Matematis. Volume 3 No.1.

Muh. Anis Rasyid, Mega Teguh Budiarto, Agung Lukito. 2017. Profil Berfikir Reflektif Siswa SMP dalam Pemecahan Masalah Pecahan Ditinjau dari

Perbedaan

Gender. http://journal.unnes.ac.id/nju/index.php/kreano

Nenny Indrawati dan Nurfaidah Tasni. 2016. Analisis Kemampuan Pemecahan Masalah Berdasarkan Tingkat Kompleksitas Masalah dan Perbrdaan Gender. Jurnal Saintifik. Vol.2 No 1. 
Nurmitasari dan Robia Astuti. 2017. Tingkat Berfikir Kreatif Siswa MTs. Pada Bangun Datar Ditinjau dari Jenis Kelamin. Jurnal Edumath. Volume 3 No. (2017) Hlm. 118-128.

Retno Sari, Tri Atmojo Kusmayadi, Imam Sujadi. 2016. Aktivitas Metakognisi dalam Pemecahan Masalah Matematika Ditinjau dari Gender Siswa Kelas VII SMP Negeri 1 Nanggulan Kabupaten Kulon Progo. Jurnal Elektronik Pembelajaran Matematika. Vol.4 No.5, hal 496509 ISSN : 2339-1685.

Syahrir. 2016. Pengembangan Perangkat Pembelajaran Matematika SMP untuk Meningkatkan Kemampuan Berfikir Kreatif. JIME. Volume 2 No. 1 ISSN 2442-9511. 